\title{
Vatandaş - İdare Etkileşimi Bağlamında Bilgi Edinme Hakkı: BİMER Örneği ve İdarede İnovasyon
}

\author{
Naci KARKIN* \\ Akın ZOR ${ }^{\star *}$
}

Öz

$\mathrm{Bu}$ çalışma, klasik kamu yönetimi kuramında halkla ilişkiler kavramı çerçevesinde şekillenen ve gelişen vatandaş-idare etkileşimi ve bunun olumlu yönlerini konu almaktadır. Gelişen teknolojik olanaklar çerçevesinde, vatandaşların idareye müracaatları ve idarenin bu müracaatlara cevapları, idarede inovasyonu geliştirecek potansiyel barındırmaktadır. Çalışma, kronolojik bağlamda, 1982 Anayasası ile başlayan dönemi temel almaktadır. İlgili anayasada "dilekçe hakkı" ile başlayan idareye müracaat kavramı, gelişen yeni imkânlar, kuramsal değişimler, uluslararası gelişmeler vb. faktörlerin de yardımıyla son derece değişik araç ve olanaklarla desteklenmiş, artık klasik halkla ilişkiler kavramıyla tanımlanamayacak bir dönüşüm göstermiștir. Bilgi edinme hakkı, Kamu Denetçiliği Kurumu’na (Ombudsman) müracaat hakkı, Başbakanlık İletişim Merkezi (BİMER) ve Cumhurbaşkanı'na Yazın (CİMER) uygulamaları gibi olanaklar, vatandaş ile idare arasındaki geleneksel tek yönlü ilişkinin, çift yönlü ilişkiye dönüşmesine yardımcı olmaktadır. Bu olanaklar, içerisinde, idarenin karşılaştığı yönetsel sorunlara dönük inovatif çözümler sağlama potansiyeli de barındırmaktadır. Bu çalışmada, başta BİMER olmak üzere vatandaş ile idare arasındaki etkileşimlerin, geleneksel tek yönlü idare-vatandaş ilişkisini etkileşime dönüştüreceği, hem de söz konusu etkileşimin idarenin muhtaç olduğu inovatif dönüşümü sağlayacağı iddia edilmektedir.

Anahtar kelimeler: Halkla İlişkiler, İdare-Vatandaş İlişkisi, Bilgi edinme hakkı, BİMER, İnovasyon

\section{Right to Information in the context of Citizen-Administration Interaction: Case of BIMER and Innovation}

\begin{abstract}
This study deals with the interaction between citizen-administration, which is shaped and developed in the concept of public relations within classical public administration theory and its positive aspects. Within the scope of developing technological opportunities, citizens' applications to the administration and the answers to these applications have the potential to improve innovation for the administration. In the chronological context, the study is based on the period beginning with the Constitution of 1982 . The

* Doç. Dr., Pamukkale Üniversitesi, İktisadi İdari Bilimler Fakültesi, Siyaset Bilimi ve Kamu Yönetimi Bölümü, nkirgin@pau.edu.tr

** Kaymakam, Yükseklisans Öğrencisi, Pamukkale Üniversitesi, SBE, Yönetim Bilimleri ABD, akin_zor@hotmail.com
\end{abstract}


concept of the application to the authority starting with the "right to petition" in the relevant constitution, is supported with the help of various tools and facilities such as developing new possibilities, theoretical changes, international developments and so on, has shown a transformation that it cannot be defined by the concept of classical public relations anymore. Facilities such as the right to information, the right to appeal to the Turkish Ombudsman Office, Prime Ministry Communications Centre (BİMER) and write to President (CIMER) help to the transition from traditional one-way relationship between the citizen and the administration to a two-way relationship. These possibilities also include the potential to provide innovative solutions to the managerial problems that the administration is facing. In this study, it is claimed that the interactions between the citizen and the administration, notably BIMER, will transform the traditional one-way administrative-citizen relationship to interaction, and this interaction will provide an innovative transformation that the administration needs.

Keywords: Public Relations, Citizen-Administration Relations, Right to Information, BİMER, Innovation

\section{Giriş}

Vatandaşın idareye müracaatı, geleneksel kamu yönetimi anlayışında "halkla ilişkiler" fonksiyonu çerçevesinde kurgulanmıştır. Yöneten-yönetilen arasındaki ilişkinin oldukça ayrışmış olduğu dönemler ve yapılar itibariyle, idare edilenin (vatandaş-yurttaş) idareye (devlet kurumları kamu yönetimi) müracaatının aracılı, dolaylı bir süreç olması söz konusudur. Bu süreçte, ayrıca, ilk aşamada doğrudan idareciye değil, idareye ulaşabilme biçiminde bir kurgu bulunmaktadır. İdarenin ise, "müracaatın kendilerine ulaştığını ve ilgili müracaatın işlemde/incelendiğini” bildirmesi yeterli olduğu gibi, sonuç itibariyle, ilgi müracaata bunun dışında cevap vermek zorunda olmaması bile olanaklıdır. Bu açıdan değerlendirilirse, idare-vatandaş ${ }^{1}$ ilişkisinde gizlilik/kapalılık oldukça uzun bir dönem esas olurken, açıklık/şeffaflık/hesap verebilirlik gibi kavramlar, son dönem itibariyle kabul görmeye başlamıştır. Bu yöndeki çabalar, gelişen ve dönüşen teknolojik uygulamalar yardımıyla (örn. açık veri, açık hükümet vd.) giderek güçlenme eğilimi göstermektedir. Yine de, an itibariyle, dünyanın hiçbir ülkesinde devlet-vatandaş arasındaki etkileşimler, devlet sırrı gerekçesiyle, tüm boyutlarıyla açık, şeffaf ve hesap verebilir değildir.

$\mathrm{Bu}$ çalışma, idare-idare edilen arasındaki ilişkinin boyut değiştirerek, idare edilenlerin de idareye katkı verebileceği savı üzerine şekillenmektedir. Özellikle gündelik yaşamlarında vatandaşlar, kamu yönetimi ile çok boyutlu bir etkileşime girmek durumundadır. Söz konusu etkileşimde karşılaşacakları sorunları, engelleri, iyi uygulamaları, bozulmuşlukları veya en son kertede yozlaşmaları, idareye veya seçilmişlere (örneğin, Başbakanlık İletişim Merkezi - BİMER veya Cumhurbaşkanı’na Yazın - CİMER marifetiyle devletin en üst makamlarında yer alan seçilmişlere) adalet, doğruluk ve hakkaniyet çerçevesinde iletmeleri mümkündür ${ }^{2}$. Bu açıdan bakılırsa, idare,

1 İdare - vatandaş ilişkisi ile kastedilen, aslında kamu otoritesi ile bu otoriteye muhatap olan herhangi bir bireydir.

2 Aksi durumlar da söz konusu olabilir. Örneğin, Amasya Belediyesi’ni BİMER'e şikayet eden bireyin amacı kamu yararına dönük bir faaliyeti engellemeye dönük olabilir. O zaman ciddi bir filtreleme gerekir. Sistemi amacı dışında veya yanlış bilgi ve beyanlarla idareyi yanıltma amacı güdenlere de mer'i mevzuat bağlamında işlem yapılabilir (http://www.hurriyet.com.tr/bimere-sikayet-dagin-altinda-hazine-var-40128272). 
sadece kamu görevlileri değil, idare ile etkileşime giren birey sayısı kadar muhataba sahip olması imkân dâhilindedir. İdarenin, çalışanlarının yanında, her bir vatandaştan da girdi (ihbar, şikâyet, öneri, eleştiri, teşekkür) alabilmesinin önü açıktır. Kuramsal olarak; idare, vatandaşlardan girdi almak marifetiyle, sorunlu yönlere çok ivedi olarak müdahale edebilir, eylem ve işlemlerini daha iyi hale (betterment of public services) getirebilir. Dolayısıyla, idare sürekli inovatif bir yapıya sahip olabilir. Şüphesiz, söz konusu inovatif sürecin bazı şartları da bulunmaktadır. Bu şartların en tepesinde, siyasal liderlik olarak tanımlanan kavram yer almaktadır. İdarenin işlem ve eylem kabiliyetinin harekete geçirilmesi ve yönlendirilmesinde olduğu gibi, korunmasında ve kollanmasında en yaşamsal destek, siyasal liderlikten gelmektedir. Başta Cumhurbaşkanı olmak üzere, Başbakan ve hükümet üyelerinin emir ve talimatları çerçevesinde hareket eden kamu yönetimi aygıtının, söz konusu inovasyonu sağlayabilecek bir yapıya dönüşmesinde siyasal liderliğin desteği, sürekli ve eksiksiz olmak durumundadır. Ayrıca, idare mensuplarının, vatandaşlardan gelecek girdiyi kabul etmeye hazır olmaları; vatandaşı, paydaş olarak kabul etmeleri son derece önemlidir.

Bu çerçeveden hareket edilirse, bilişim ve iletişim teknolojileri - BİTler başta olmak üzere gelişen teknolojik olanaklar, idare-vatandaş ilişkisinin dönüşmesi; yönetilenlerin, yönetim veya kamu hizmeti üretim sürecinin aktif bir parçası olmasının önünün açılması noktasında son derece yararlı işlevsellikler barındırmaktadır. Söz konusu olanaklar içerisinde, çalışmanın konusunu oluşturan BİMER uygulaması, vatandaşın idareye müracaatında (ihbar, şikâyet, öneri, bilgi edinme vd.) son derece önemli işlevsellik sağlayabilir. Bu işlevsellik, idarenin kendisine ulaşan girdiyi veri kabul edip, çözüm sağlamanın ötesinde, aynı türden sorunların bir örneği olarak işlemesi durumunda söz konusudur. Bu noktada BİMER, içerisinde idarenin ihtiyacı olan inovasyonu sağlayabilecek potansiyel barındırmaktadır.

Bu çalışmada, ilk olarak kavramsal bir çerçeve verilecektir. İlk bölümde, idare-vatandaş ilişkisinin geleneksel çerçevesi olan halkla ilişkiler kavramı anlatılacak, daha sonra vatandaşların idareye müracaatlarını düzenleyen yasal düzenlemeler hiyerarşik bir sıralama içerisinde tartışılacaktır. İkinci bölümde, vatandaşın idareye müracaatını düzenleyen metinler içerisinde, BİMER genelgesi ve BİMER uygulaması analiz edilecektir. Üçüncü bölümde, tartışma ve sonuç yer almaktadır.

\section{Kavramsal Çerçeve: Halkla iliş̧iler Kavramı}

Halkla ilişkiler kavramının üzerinde oydaşım sağlanmış, kabul gören ve genel geçer bir tanımının olmadığı (Akyürek \& Solmaz, 2003) görülmekle birlikte, buna dönük çabaların varlığ1 da kuşkusuzdur (Örn. Harlow, 1975; 1976; 1977; 1980). Hutton (1999) bir çalışmasında, Harlow'un, 472 farklı tanım ve alanda çalışan 65 profesyonelden elde ettiği katkılar sayesinde, halkla ilişkilerin tanımını geliştirebildiğini ifade etmektedir. İlgi tanıma göre halkla ilişkiler ${ }^{3}$

\footnotetext{
"Public relations is a distinctive management function which helps establish and maintain mutual lines of communication, understanding. acceptance and cooperation between an organization and its publics; involves the management of problems or issues; helps management to keep informed on and responsive to public opinion; defines and emphasizes the responsibility of management to serve the public interest; helps management keep abreast of and effectively utilize change, serving as an early warning system to help anticipate trends; and uses research and sound and ethical communication techniques as its principal tools" (Harlow 1976, p. 36).
} 
şöyle ifade edilebilir: "Halkla ilişkiler, herhangi bir kurum ile onun muhatapları arasında iletişim, anlama, kabul ve işbirliği olanakları geliştirilmesine ve sürdürülmesine yardımcı olan özgün bir idari fonksiyondur. Halkla ilişkiler, sorun veya meselelerin yönetimini içerir; idarenin haberdar olmasına ve muhataplarına yanıt verebilmesine yardım eder; idarenin kamu çıkarına hizmet etme sorumluluklarını belirler ve vurgular; idarenin değişime uyum sağlamasını ve değişimi etkin kullanmasına yardım eder, böylece muhtemel eğilimlerin önceden tahmin edilmesine hizmet eder ve başat araçlar olarak araştırma ve ahlaki iletişim tekniklerini kullanır” (Harlow, 1976, s.36). Kavramın bu kadar farklı tanımının üretilebilmesi, üzerinde oydaşım sağlanan bir tanımın kolaylıkla bulunamaması, salt halkla ilişkiler alanında söz konusu değildir. Benzer bir zorluğun diğer disiplinlerdeki bazı kavramlarda da görmek olanaklıdır. Bu zorluğun kaynaklarından bir tanesi, ilgili alanın farklı birçok disiplinlerin kesişim alanında olmasıdır. Dolayısıyla, kesişim alanında olmak, hem etkilenme hem de etkilemeyi beraberinde getirmektedir (örn. yansıma (reflexivity) özelliği, Şaylan, 2000). Bunun yanında, halkla ilişkiler alanında, iletişim, kültür ve teknolojik gelişim ile beraber yaşanan geniş anlam değişimi de söz konusu tanımların farklılaşmasına bir gerekçe oluşturabilir.

Kelime anlamları bağlamında değerlendirildiği zaman, Türk Dil Kurumu sözlügünde 'halk' kavramı beş farklı biçimde tanımlansa da, çalışmanın özüne en uygun tanım "Bir ülkedeki yurttaşların bütünü, kamu” tanımıdır (TDK, t.y. a). Yine TDK'ya göre 'ilişki' ise “iki şey arasında karşılıklı ilgi, bă̆, münasebet, temas" olarak tanımlanmaktadır (TDK, t.y. b). Bu iki sözcük birlikte anlamlandırıldığında, halkla ilişkiler kavramının, kamu, özel ve sivil sektörde yer alan örgütlerin, bireysel ve örgütsel muhatapları ile sağlıklı bir etkileşim kurmasını sağlayan bir süreci anlatmakta olduğunu ifade edebiliriz. Giderek bilinçli hale gelen bireylerin, herhangi bir örgüte dönük tepkilerini belirleyen önemli etmenler arasında, ilgili örgütün muhataplarına dönük yaklaşımı son derece önemli hale gelmektedir. Bu bağlamda değerlendirildiğinde, bireyler artık satın almış oldukları malların veya hizmetlerin kaliteli olmasının yanında, onu üreten kurumların kurumsal iletişim tarzlarına, misyonlarına, vizyonlarına ve donanımlarına da dikkat etmektedir (Başok \& Coşkun, 2012).

\section{Kamu Yönetimine Bireysel Başvuru}

İdare, örgütlenmiş, değişime uğrasa da belirli bir geleneğe sahip, son derece yıkıcı ve yapıcı güçleri olan bir aygıt olarak tanımlanırsa, bu aygıtın karşısında birey(ler)in gücü, olanakları ve karşı durabilme yeteneği son derece sınırlıdır (ayrıca, Kırışık, 2013). Bu bağlamda değerlendirilirse, idarenin egemenlikten kaynaklanan güç ve otoritesinin bireylerin hakları karşısında sınırlanmasına dönük çabalar, başta hukuki yollar (idarenin yargısal denetimi) olmak üzere, yargı dışı başvuru yollarının da (örn. bilgi edinme hakkı, dilekçe hakkı, ombudsmana müracaat vd.) gelişmesine zemin hazırlamıştır (Fendoğlu, 2013).

Hak aramak amacıyla, bireyin idareye başvurabilmesi ile hukuk yolları kullanarak hak aramasının tamamen farklı olduğunu belirtmek gerekir. Siyasal sistemler ve ülkeler arasında farklılık olsa da, 
bireyler idareye dönük haklarını hukuk usulüne uyarak, mahkemeler nezdinde arayabilir. Elbette, bunun usulü ve esası ülkeler arasında, yapı, sistem ve kültürden kaynaklı değişim gösterebilir. Dolayısıyla hukuki yol ve yöntemler ile hak arama, bu çalışmanın dışında kalmaktadır. Bu çalışmada sözü edilen bireysel başvurular, öncelikle doğrudan idareye ${ }^{4}$ yapılan müracaatları içermektedir. Bu müracaatların amaçları arasında, duruma göre, idarenin söz konusu işlem ve eylemlerini ortadan kaldırmasını veya uğranılan zararı telafi etmesini sağlamak yer alabilir. Daha da önemlisi, söz konusu olumsuz değerlendirilen eylem ve işlemlerin, sonraki benzer durum ve olaylarda aynı şekilde tekrarının önlenmesi çabası, idareye müracaatın amaçları arasında önemsenmelidir.

Günümüzde ortaya çıan değişim ve dönüşümlere, ayrıca söz konusu değişim ve dönüşümleri hızlandırıcı teknolojik olanakların varlığına rağmen, halkla ilişkiler süreci ve idarenin yargısal/ yargı dışı denetim olanaklarının kategorik olarak hala “idarenin denetimi” işlevi bağlamında değerlendirilmesi dikkat çekicidir. Burada dikkat çekici olan, idarenin kendi örgütsel yapısının dışında değerlendirdiği tüm eylem, işlem ve süreçleri “denetim” başlığı altında "dışsal” bir sürecin ürünleri olarak görme eğiliminin hala devam ediyor oluşudur ${ }^{5}$. Ĕger, idare, vatandaşı paydaş olarak kabul edebilirse; o zaman bireysel müracaatlar ve bu müracaatların sonuçları, içsel bir sürecin parçası olarak değerlendirilebilir. Aksi halde, bireysel müracaatlarda arzu edilen neticenin dahi ortaya çıkmış olması, esasa ilişkin bu "içsellik-dışsallık" sorunsalının önemini azaltmayacaktır. Bu bağlamda, iç süreçler ile dış süreçlerin etkileri karşılaştırmalı olarak değerlendirilse, içerden gelen veya içten geldiği kabul edilen gücün üreteceği değişim ve dönüşümün, dıştan gelen veya dışsal kabul edilen gücün üreteceği değişim ve dönüşüme göre etkisi son derece baskın olacaktır. O zaman, denilebilir ki, vatandaştan gelebilecek doğru, adil ve hakkaniyetli veriler, idarenin süzgecinden geçirildikten sonra sürekli iyileşme için kullanılabilir, yönetim sürecine sürekli bir girdi sağlayabilir.

4 Çalışmanın konusunu oluşturmamakla birlikte, bireylerin, idarenin eylem ve işlemlerini etkileyebilecek olan kurumlara (örn. ombudsmanlık, Fendoğlu, 2013) veya parlamentoya müracaatlarını da (örn. dilekçe hakkı, Aydın 2004), hukuksal müracaatlardan ayrı tutmak gerekir. Hukuksal yolların uzun olması, masraflı olması, hukuki makamların iş yoğunluklarının azaltılmasına yardımcı olma isteği (Demirkol, 2012) ve yasal yolların çok fazla biçimsel olmasına (Hatipoğlu, 2014) koşut biçimde, idare ile bireyler arasında aracılık yapabilecek kurumlara duyulan ihtiyaç ortadadır. Sonuçta, ombudsmanlık kurumuna yapılan müracaatlar da, doğrudan idareye yapılan müracaatlar gibi bireyseldir. Sonuçları bireysel olmakla birlikte, verilen tavsiye kararlarının "emsal olușturma” yönünün bulunması, kamu yönetiminin inovatif olma iradesine ciddi katkı sağlayabilecek yönünü ortaya çıkarmaktadır. Ombudsmanlık kurumunun ana hareket kabiliyetinin, bireylerden gelen müracaat olduğu not edilmeli, kurumun re'sen harekete geçme kabiliyetinin (Efe \& Demirci, 2013) ülkeler arasında farklılık gösterebileceği dikkate alınmalıdır.

5 Türkiye Büyük Millet Meclisi (TBMM) Başkanlığı, bilgi edinme hakkının T.C. Anayasası’na dâhil edilmesine ilișkin yaptığı basın açıklamasında da bilgi edinme sürecinin içsel bir süreç olmadığı, dışsal ve denetsel bir sürece ait olduğunu tespit ve teyit etmektedir: "Ülkemizde de 12 Eylül 2010 Anayasa Referandumu ile bilgi edinme hakkı, Anayasanın 74 üncü maddesine eklenmiştir. Demokratik yönetim anlayışının ve hukukun üstünlüğünün unsurlarından biri olan bilgi edinme hakkı, açıklık ve şeffaflğın sağlanmasında önemli bir haktır. Yönetimin haklar üzerinde değişiklikler yapabilme gücü karşısında, kamunun ya da bireylerin çatışan çıkarların dengelenmesi idari uygulamalardan haberdar olunmasıyla mümkündür. Diğer yandan kamu kaynaklarıyla üretilen bilgilere erişim hakkının, yönetimin karar alma süreçlerinin hukuka uygunluğu ile işve eylemlerinin denetlenmesi açısından gerekliliği açıktır. Yönetimle ilgili bilgi sahibi olma ve yönetimin denetlenebilmesi ayn zamanda bireye yakın yönetimin oluşmasına ve kamuya duyulan güvenin artmasına da yardımcı olmaktadır."(TBMM, t.y. a) 


\section{Türk Kamu Yönetiminde Bireysel Başvurular ve Bilgi Edinme Hakkı}

Sosyal bir varlık olarak insanların bir araya gelerek oluşturdukları toplumlar, sahip oldukları farklı kültürleri ile birbirinden ayrışmaktadır. Alaeddin Asna, kültürü, belirli bir bölgede bulunan insanların ortak biçimde paylaştığı inançlar, değerler, hareket ve davranış kalıplarının bir bütünü olarak değerlendirmektedir (Asna, 2012). Bireylerin bilgiye ulaşma ve bunu kullanma isteğinin, kişilerin eğitimleri ve (siyasal) kültür düzeyleri ile etkileşim içerisinde olduğu savlanabilir. İstisnalar bir tarafa konulsa, eğitim ve (siyasal) kültür düzeyinin artması ile bireyler, siyasal, sosyal olay ve olgulara dönük daha bilinçli ve daha duyarlı bir tavır geliştirebilir. Genel olarak, bilgi ve bilgiye erişim yolları, söz konusu bireyler için oldukça önem arz eder bir hale gelir. Bu noktada, bireylerin bilgi edinme ihtiyaçları, salt kamusal değil, özel sektör firmaları ve sivil toplum örgütlerine dönük de olabilir. Yalnız bu çalışma, söz konusu bilgi ve bilgi edinme yolları ve kamu yönetimine başvuruyu temel aldığ için vatandaşların kamu kurum ve kuruluşlarından bilgi edinme yollarına ve kamu yönetimi ile olan etkileşime odaklanacak, bunun dışındaki ihtiyaçlara değinilmeyecektir.

Türkiye’de başta siyasal kültürün ve eğitim düzeylerinin artmasına koşut biçimde, vatandaşların başta günlük hayatlarında karşılaştıkları sorunları çözme, şikâyetlerini veya memnuniyetlerini ilgili kurumlara iletme temelinde, bilgi edinme ve yönetime katılım talebi, giderek gözlenebilir bir hal almaktadır. Başta siyasal kurumlar olmak üzere, yönetimin bireylerin bu yöndeki beklentilerini gidermeye yönelik çaba, adım ve ilgili düzenlemelerini de izlemek olanaklıdır. Bu çerçevede, öncelikli olarak vatandaşların başvuru ve bilgi edinme hakları, anayasal düzeyde güvence altına alınmıştır. 12 Eylül 2010 Anayasa Referandumu ile Türkiye Cumhuriyeti Anayasası́nın bazı maddelerinde değişiklikler yapılarak ${ }^{6}$, bilgi edinme hakkı bir bütün olarak başta 74 . madde olmak üzere, anayasanın değişik maddelerine işlenmiştir. Bu açıdan, yasal mevzuat içerisinde ise, 1984 tarihli ve 3071 sayılı “Dilekçe Hakkının Kullanılmasına Dair Kanun” ve 2003 tarih ve 4982 sayılı “Bilgi Edinme Hakkı Kanunu” öne çıkmaktadır.

Bu çalışma, Türkiye’de bilgi edinme hakkına ilişkin yasal ve idari düzenlemelerden hareket edeceği için buna ilişkin temel belgeler üzerinde durmak yararlıdır. Bu bağlamda söz konusu belgelerin ilki, 3071 sayılı "Dilekçe Hakkının Kullanılmasına Dair Kanun”dur. İkincisi, 4982 sayılı "Bilgi Edinme Hakkı Kanunu”dur. Ayrıca, bu kanuna dayanılarak 27.4.2004 tarihli Resmi Gazete’de yayımlanan "Bilgi Edinme Hakkı Kanununun Uygulanmasına İlişkin Esas ve Usuller Hakkında Yönetmelik” de önemlidir. Üçüncüsü de, 24.01.2004 tarihli Resmi Gazete’de yayımlanan 2004/12 sayılı ve "Dilekçe ve Bilgi Edinme Hakkının Kullanılması" konulu Başbakanlık Genelgesi ile 20.01.2006 tarihli Resmi Gazetede yayımlanan 2006/3 sayılı ve “Başbakanlık İletişim Merkezi (BİMER) - Doğrudan Başbakanlık” hakkında Başbakanlık Genelgesi de üzerinde durulacak mevzuat arasındadır.

$6 \quad$ Bilgi edinme hakkının anayasaya dâhil edilmesi 12 Eylül 2010 referandumu ile olanaklı hale gelmişse de, aslında mevzuatımızda bilgi edinme hakkı, yasal düzeyde 2003 yılında gerçekleşmiştir. Türkiye Cumhuriyeti Anayasası’nın 74. maddesinin kenar başlı̆̆ “ "Dilekçe Hakkı" iken, 12 Eylül referandumu ile birlikte bu maddenin kenar başlığı hem bilgi edinme hakkına atıf vermesi hem de kamu denetçisine (ombudsman) başvurabilmeyi içermesi bağlamında değiştirilmiştir. 


\section{I sayılı Dilekçe Hakkı'nın Kullanılmasına Dair Kanun}

Bilindiği üzere, anayasada yer alan her hangi bir hakkın - dilekçe hakkı dâhil - kullanılabilmesi için gerekli yasal ve idari düzenlemelerin yapılması gerekmektedir. Bu çerçevede, 1.11.1984 tarihinde anayasal dilekçe hakkının yasal altyapısı oluşturulmuştur. İlgili “Dilekçe Hakkının Kullanılmasına Dair Kanun"un birçok hükmünün, başta 2003 yllı olmak üzere, 2011 yılında değiştiği izlenmektedir. Dilekçe hakkını düzenleyen mevzuatta, bu hakkın daha çok parlamento nezdinde kullanımının düzenlendiği izlenmektedir (T.B.M.M. t.y. b). Her ne kadar, 3071 sayılı kanun sarih biçimde “...kendileriyle veya kamu ile ilgili dilek ve şikâyetleri hakkında, Türkiye Büyük Millet Meclisine ve yetkili makamlara yazı ile başvurma haklarının...” (3071 sayılı Kanun, Madde 1) ifadesine yer verse de, 1982 Anayasası'ndan ve 3071 sayılı yasal düzenlemeden önceki dönemde çıkarılan (12.26.1962) ve 2007 yılında ilga edilen 14 sayılı “Türk Vatandaşlarının Türkiye Büyük Millet Meclisine Dilekçe İle Başvurmaları ve Dilekçelerinin İncelenmesi ile Karara Bağlanmasının Düzenlenmesine Dair Kanun” ve TBMM İçtüzügü’nün dilekçe ile ilgili maddeleri, dilekçe hakkının daha çok seçilmişler marifetiyle kullanılmasını öne çıkarmaktadır. Bu anlamda değerlendirilirse, bilgi edinme hakkının ve idareye doğrudan ve aracısız müracaatı düzenleyen diğer yol ve yöntemlerin ihdas edilmesi, son derece yerinde bir düzenleme olarak gözükmektedir. Elbette 4982 sayılı "Bilgi Edinme Hakkı Kanunu”nun kendisinden önceki 3071 sayılı kanunla getirilen hakların kullanımına engel oluşturmayacağı hükmü de (4982 sayılı Kanun, Madde 2) son derece yerinde bir hüküm olarak değerlendirilmektedir.

\section{Sayılı Bilgi Edinme Hakkı Kanunu (BEHK)}

Bilgi edinme hakkı ve bu hakkın uygulanması, genellikle, yasal düzeyde tanınmış bir hak olup; Türkiye, Macaristan, Polonya, Avusturya gibi bazı ülkelerde, bu hakkın anayasal düzlemde de kabul edildiği görülmektedir. 18.yüzyılın ilk yarısından itibaren, ombudsmanlık kurumunun da örnek model olarak kurgulandığı İsveç’te, bilgi edinme kanunu ile ilgili ilk düzenlemeler yapılmış; ilerleyen dönemlerde ise, başta ABD’deki 1950’lerdeki "günışı̆̆ı" yasalarıyla, bilgi edinme hakkı ve bu haktan doğan uygulamalar, tüm küreye genişlemiştir (Şengül, 2008).

Ülkemizde, bilgi edinme hakkı ile ilk adımın 2002 yılında işbaşına gelen Adalet ve Kalkınma Partisi'nin (AK Parti) 58. Hükümet programı çerçevesinde atıldığı görülmektedir ${ }^{7}$ (T.B.M.M. t.y. c) Bu bağlamda, başta 59. Hükümetin TBMM Başkanlığına sevk ettiği Bilgi Edinme Hakkı Kanunu Tasarısı'nın “Genel Gerekçesi” olmak üzere (T.B.M.M. t.y. d), 58. ve 59. Hükümetlerin programlarında başta e-devlet, BİT kullanımının yaygınlaşması olmak üzere bilgi edinme hakkı

İlgi hükümeti takip eden ve dönemin Başbakanı Sayın Erdoğan tarafından kurulan 59. Hükümetin TBMM Başkanlığı'na sevk ettiği ilgi kanun tasarısının "Genel Gerekçesi”nde, bilgi edinme hakkının işlev ve amaçları şöyle tanımlanmaktadır: "Demokrasinin ve hukukun üstünlü̈̆̈̈nün gereklerinden olan bilgi edinme hakkı, bireylere daha yakın bir yönetimi, halkın denetimine açıklı̆̆l, şeffaflı̆̆ sağlama işlevlerinin yanı sıra halkın Devlete karşı duyduğu kamu güvenini daha yüksek düzeylere çıkarmada önemli bir rol oynamaktadır. Kullanılan bu hak sayesinde hem halkın Devleti denetimi kolaylaşmakta hem de Devletin demokratik karakteri güçlenmektedir." (T.B.M.M. t.y. e) 
ve bu hakkın kullanımını destekleyecek, genişletecek ve sürdürecek yapısal önlem ve işlemlerden siklıkla söz edilmektedir ${ }^{8}$.

Ülkemizde bilgi edinme hakkına dönük yasal ve idari düzenlemelerin gerçekleştirilmesinin dışsal gerekçelerle ${ }^{9}$ başladığını ve sürdürüldügünü, fakat henüz bu sürecin içselleştirilmediğini iddia etmek olanaklıdır. 2002 yılında süreci başlatılan ve 2003 yılında kabul edilen bilgi edinme hakkının uygulanması sürecinde bazı sorunlarla karşılaşılmıştır (Aras \& Altınok, 2009). Öncelikle, "devlet sırrı" 10 (Polater, 2016) kavramının ne olduğuna ve bu kavramın neleri kapsadığına ilişkin yasal altyapı henüz tamamlanmamıştır. Bu nedenle idarenin, bilgi edinme taleplerinin bazılarına ilişkin olumsuz cevap vermemesi çerçevesinde, Bilgi Edinme Değerlendirme Kurulu'na (BEDK) ${ }^{11}$ müracaat olanağı sağlanmıştır. Bunun yanında, keyfi olarak bu hakkın kullanımını engelleyen kamu görevlisine dönük ne gibi yaptırımların (Küçük, 2011) olacağına ilişkin uygulamada bazı yol ve yöntemler belirtilmişse de (örn. disiplin cezası için üst idari makamlara şikâyet veya Cumhuriyet Başsavcılı̆̆g’na suç duyurusu), bu yolların, sonraki uygulamalar bağlamında caydırıcılığının ortaya konulması gerekmektedir.

8 "Bilgi edinme hakkı, toplumun bütün kesimlerine yaygınlaştırılacak ve bunu sağlamak için "Vatandaşın Bilgi Edinme Hakkı Kanunu” çıkarılacaktır. Bu kanunun taslağı hazırdır ve Ak Partinin katılımcı siyaset anlayışı çerçevesinde, vatandaşlarımızın bilgisine, eleştirilerine ve katkılarına açılmıştır.

Yeni bilgi ve iletişim teknolojilerinden yararlanılarak, kamu kuruluşlarının hizmet ve işlemleri halka duyurulacak, yönetimde şeffaflık să̆lanacaktır.

Kamuda verimliliğin artırılması ve şeffaflı̆̆ın sağlanması için hizmet birimlerinin, Parlamentoya ve kamuoyuna performans raporu sunmaları yönünde çalışmalar başlatılacaktır.

Kırtasiyecilik, şekilcilik ve verimsizliğin azaltılması bakımından; vatandaşa doğrudan hizmet sağlayan alanlarda mevzuat ve idarî usuller sadeleştirilecektir

Kamu kuruluşlarında bilgi ve iletişim teknolojileri azamî ölçüde kullanılarak, e-devlet uygulaması yayginlaştırılacaktır."(T.B.M.M. t.y. d)

9 Başta Anayasa olmak üzere mevzuatımızda - devlet sırrı gibi istisnalar hariç - bilgi edinme hakkını destekleyen veya engelleyen hiçbir hükmün bulunmaması (T.C. Başbakanlık, 2003); bunun yanında, gerek teamüllerde, gerek yönetim yapı ve sistemimizde açıklığın istisna, kapalılığın ise; genel kural olması (Güran, 1982; Eken, 1994; Şengül, 2005; Çevikbaş, 2006; Çımat, 1997’e atfen İnaç \& Ünal, 2007; Akyıldız \& Demir, 2011; Yılmaz, 2015) bilgi edinme hakkına ilișkin düzenlemelerin temel motifinin, dış kaynaklı olduğunu göstermektedir. Yine de, Akyıldız ve Demir (2011), bilgi edinme hakkını düzenleyen yasal düzenlemelerle sağlanacak açıklık ilkesinin, kapalılığı verimlilik ilkesi olarak gören geleneksel kamu yönetiminin aksine, çağdaş kamu yönetiminin - şeffaflık ve hesap verebilirliğin tam sağlanması koşulu altında - verimli çalışmasının önkoşulu olarak kabul edildiğini, bu çerçevede, kamu yönetiminde verimsizliğin azaltılacağını düşünmektedir.

10 Devlet sırrı kavramı, Anayasa'da yer bulan bir kavram (düşünce ve ifade hürriyetinin tahdidi bağlamında, Akkaya Kia 2013) olmakla birlikte, kavramın neleri kapsadığına ilişkin yasal ve ikincil mevzuat oluşmamıştır. Dolayısıyla, devlet sırrının neyi kapsadığının netleştirilmemesi bilgi edinme hakkının önünde ciddi bir engel ve gerekçe kümesi oluşturmaktadır. Devlet Sırrı Kanun Tasarısı, 2008 yılında TBMM Başkanlığı’na sevk edilmesine rağmen, kadük kalmış, 2011 yılında ilgi tasarı TBMM Başkanlığı’na tekrar sevk edilmesine ve 2012 yılında ilgili komisyonlarda gündeme alınmasına rağmen, henüz kanunlaşamamıştır.

11 İdareye dönük bilgi edinme taleplerinin yerine getirilmemesi üzerine, ilgi kuruma yapılan itiraz da sonuç vermezse, konuyla ilgili olarak, 2004 yılında ihdas edilen "Bilgi Edinme Değerlendirme Kurulu”na başvurmak olanaklıdır. (T.C. Başbakanlık BEDK 2015). Başka bir yayınında, BEDK, misyonunu ise, söyle açıklamaktadır: "4982 sayılı Bilgi Edinme Hakkı Kanunu ve ilgili mevzuat uyarınca yapılan bilgi edinme başvurularıla ilgili yapılacak itirazlar üzerine verilen kararları incelemek, bilgi edinme hakkının kullanılmasına ilişkin görüş ve değerlendirme istemini içeren başvuruları karara bağlamak ve kurum ve kuruluşlar için bilgi edinme hakkının kullanılmasına ilişkin hususlar düzenlemek" (T.C. Başbakanlık BEDK 2014). 
Başta devlet sırrı olmak üzere ilgili kanunun 14. maddesinde karşılığını bulan sınırlamalar, açıklık, hesap verebilirlik ve saydamlığa gölge düşürmesinin yanında, ihtiyaç duyulan bilgi ve belgelere ulaşımı olumsuz etkilemektedir. Devlet-vatandaş ilişkisinde kritik bir öneme sahip "devlet sırrı" unsurunun çerçevesinin çizilmemesi, bilgi edinme hakkının vatandaşlarca etkin bir şekilde kullanılmasını etkilemektedir (Hasdemir, 2014). İlgili mevzuatın, vatandaş açısından çok önemli olan bazı konuları kapsam dışında tutmasına rağmen, bireyler, idarenin yasayı uygulamasından ve uygulamanın genel sonuçlarından memnundur (Kazancı, 2013).

Külcü ve Turan, (2013)'a göre, talep edilen bilgi ve belgelerin ilgili özel ve tüzel bireylere sağlanması ${ }^{12}$ ve bilgi hukukuna ilişkin bazı unsurlar, BEHK ile yasal çerçeveye kavuşturulmuştur. Ayrıca, bilgi edinme hakkının uygulanmasını düzenlemek amacıyla, başta "Bilgi Edinme Hakkı Kanununun Uygulanmasına İlişkin Esas ve Usuller Hakkında Yönetmelik" 13 olmak üzere diğer ikincil mevzuat zamanla hukuk âleminde yerini almaya başlamıştır. Bu bağlamda, "Bilgi Edinme Değerlendirme Kurulunun Çalışma Usul ve Esasları Hakkında Yönetmelik" 14 ve "Dilekçe ve Bilgi Edinme Hakkının Kullanılması” konulu 2004/12 sayılı Başbakanlık Genelgesi ${ }^{15}$, “Bilgi ve Belgeye Erişim Ücreti Genel Tebliği ${ }^{16}$ (Sıra No: 1)" ve "4982 Sayılı Bilgi Edinme Hakkı Kanunu ve Buna Bağlı Yönetmelik Uyarınca Karşılıklılık İlkesi Kapsamında Bulunan Ülkeler Hakkında Tebliğ ${ }^{17}$ ” gibi ikincil mevzuattan söz edilebilir.

4982 sayılı BEHK, otuz üç madde ve beş bölümden oluşmaktadır. Kanun'un genel gerekçesinde ve ilgili Meclis süresince gerçekleşen görüşmelerde saydam, hesap verebilir ve güven duyulan bir yönetim anlayışı vurgusu yapılmıştır. Kanun'un kapsamını belirten 2. maddesinde bilgi edinme hakkı başvurusunda bulunulacak merciler arasında, sadece, kamu kurum ve kuruluşları, kamu kurumu niteliğindeki meslek kuruluşları sayılmıştır. Başta özel ve sivil toplum kuruluşları olmak üzere, mahkemeler de ilgi kanun kapsamında, bilgi ve belge istemlerinden muaf tutulmuştur. Konuya ilişkin olarak, BEDK, "BEDK Kararları Işı̆̆ııda Açıklamalı Bilgi Edinme Hakkı Kanunu” isimli yayında "kapsam" sorunu taşıyan bazı müracaatları kamuoyuyla paylaşmaktadır (T.C. Başbakanlık BEDK, 2015). İlgi yayında, örneğin, 2010 yılındaki müracaatlardan birisi, bir bankadan bilgi ve belge isteminin banka şubesi tarafından karşılanması gereğini içermektedir. Kurul, Kanun'un 2. maddesini gerekçe göstererek, kendisine yapılan itirazı, kanunun kapsamı gerekçesiyle reddetmiştir. Yine kapsama ilişkin olarak, 2011 yılında kendisine ulaşan bir başka dilekçede, Yargıtay Başkanlığı 7. Ceza Dairesi Başkanlığı’na başvurulması sonrasında bilgi/belge

12 Her bireyin kendisiyle ilgili bilgi ve belge talep etmesi, yönetimin de ancak talep üzerine bilgi ve belge sağlaması, proaktif (müracaat olmadan, önceden) bir tavır olmayıp, reaktif (müracaat sonrası, sonradan) bir tavırdır. Yani, bu düzenlemeler çerçevesinde, idare kendisinden talep edilmedikçe hiçbir bilgi ve belge paylaşmak durumunda olmadığı gibi, talep edenle ilişkisi olmayan bilgi ve belgeyi paylaşması da olanaklı değildir, bunun yanında, usule uygun bilgi ve belge paylaşımı istenilmesi halinde de, idare esası gerekçe göstererek (devlet sırrı gibi) paylaşım yapmak durumunda değildir (gerekçe göstererek bilgi/belge paylaşımı reddetmek, idare açısından olanaklıdır).

24.04.2004 tarihli ve 25445 sayılı Resmi Gazete

07.06.2006 tarihli ve 26191 sayılı Resmi Gazete

24.01.2004 tarihli ve 25356 sayılı Resmi Gazete

14.02.2006 tarihli ve 26080 sayılı Resmi Gazete

17.10.2008 tarihli ve 27027 sayılı Resmi Gazete 
paylaşılmaması gerekçe gösterilerek, Kurul nezdinde buna itiraz edildiği belirtilmektedir. Kurul, Kanun'un yine kapsam maddesini göstererek, mahkemelerin ilgi kanunun kapsamına girmediği gerekçesiyle, söz konusu müracaatı oybirliğiyle reddetmiştir. Bu çerçevede, salt ilgi kanun değil, 2004/7189 sayılı "Bilgi Edinme Kanununun Uygulanmasına İlişkin Esas ve Usuller Hakkında Yönetmelik” in 2. maddesi de, ilgi kanunun kapsadığı kurum ve kuruluşları açık biçimde ve liste yöntemi ile sıralamaktadır.

Kanun'a göre, idare kendilerine ulaşan bilgi veya belgeye erişim taleplerine on beş (15) iş günü içerisinde cevap vermek durumundadır. Nitekim Kanun'un 11. maddesinde, "Kurum ve kuruluşlar, başvuru üzerine istenen bilgi veya belgeye erişimi on beş iş günü içinde sağlarlar" denilmektedir. Süre uzamasını gerektiren durumlar, ilgili yasa ve yönetmelik ile düzenlenmiştir. Kanun'un 5. maddesinde "Kurum ve kuruluşlar, bu Kanunda yer alan istisnalar dışındaki her türlü bilgi veya belgeyi başvuranların yararlanmasına sunmak ve bilgi edinme başvurularını etkin, süratli ve doğru sonuçlandırmak üzere, gerekli idarî ve teknik tedbirleri almakla yükümlüdürler" denilerek, idarenin - istisnalar dışında ${ }^{18}$ - bilgi verme yükümlülügüne vurgu yapılmıştır. İlgili yönetmeliğin 6. maddesinde idarenin alacağı bahse konu tedbirler ayrıntılı olarak açıklanmıştır.

Ayrıca, bilişim ve iletişimin hayatın olağan akışında ulaştığ 1 düzeye bakılınca, Kanun'un başvuru usulünü düzenleyen 6. maddesi ile elektronik ortamda bilgi edinme hakkının kullanılmasının da güvence altına alındığı görülmektedir. Dolayısıyla, ilgili müracaatın illa basılı veya yazılı olarak yapılmasının zorunluluğu ortadan kalkmış olmaktadır. İlgi yönetmeliğin 20. maddesinde bilgi veya belgeye erişim süreleri belirtilmekte; ayrıca, 12. maddede başvurunun reddi halinde gerekçe ve karşı başvuru yollarının gösterileceği hüküm altına alınmaktadır.

\section{4/I 2 Sayılı Dilekçe ve Bilgi Edinme Hakkının Kullanılması Konulu Genelge}

2004/12 sayılı “Dilekçe ve Bilgi Edinme Hakkının Kullanılması” konulu Başbakanlık Genelgesi ${ }^{19}$ ile bilgi edinme hakkı ile dilekçe hakkının, mevzuatta belirlenmiş esas ve usullere uygun olması koşulu bağlamında etkin kullanılmasının sağlanması amaçlanmaktadır. Bu çerçevede, başta bakanlıkların tüm teşkilatları, valilik, kaymakamlık ve yerel yönetimler ile diğer kamu kurum ve kuruluşların hizmet alanlarında uymakla mükellef oldukları kurallar ilgi genelgede açık biçimde belirtilmiştir.

Genelge’de söz konusu Dilekçe Hakkı Kanunu ve Bilgi Edinme Hakkı Kanunu ve bu kanunların uygulanmasına ilişkin olarak “....Anayasa ve ilgili Kanun hükümlerinin uygulanmasında gerekli hassasiyetin gösterilmediği, dilekçeyle yapılan başvurulara idarî makamlar tarafından bazen cevap verilmediği veya yasal süresinden sonra cevap verildiği, dolayısıla dilekçe hakkının etkin şekilde kullanımının gerçekleşmediği yolunda şikâyetler....” bulunduğuna vurgu yapılarak, siyasal irade, idarenin bu konudaki tavır ve tutumu eleştirmekte; ayrıca, siyasal liderlik olgusunun gereği

18 Bilgi edinme hakkının kullanımına engel olan bazı istisnai durumlar, kanunun 4. bölümünde “Bilgi Edinme Hakkının Sinırları" başlı̆̆ı altında belirtilmektedir.

19 24.01.2004 tarihli ve 25356 sayılı Resmi Gazete 
olarak siyaseten sorumlu Başbakan; idareye, ilgi mevzuatın tereddütsüz, derhal uygulanması talimatı vermektedir.

Genelgeye göre bütün kamu kurum ve kuruluşları aşağıda yazılı olan genelge hükümlerine uymakla yükümlüdür. Bu kapsamda, birinci maddede dilekçe hakkının demokratik bir hak olduğu vurgulanarak, ilgili $\boldsymbol{a}$ fıkrasında dilekçenin şekil şartlarına; $\boldsymbol{b}$ fikrasında dilekçe için yapılacak işlemlerin neler olduğuna değinilmiştir. Yine, genelgenin ikinci maddesinde ise bu sefer, bilgi edinme hakkının kullanımına ilişkin olarak, $\boldsymbol{a}$ fikrasında başvuruların süratle sonuçlandırılıp, istisnalar dışındaki bilgi ve belgelerin, başvuru sahibine verilmesinin önem ve gereğine vurgu yapılmıştır. Genelgenin ikinci maddesi $\boldsymbol{b}$ fıkrasında, istenilen belgelerin on beş iş günü içinde karşılanması hükme bağlanmış olup, şayet müracaat birkaç kurumu ilgilendiriyorsa, o zaman, ek on beş günlük süre daha verilmesi gereği belirtilmiştir. Genelgenin ikinci maddesi $c$ fikrasında ise bilgi edinme hakkının istisnalarına yer verilmiştir. Genelgenin ikinci maddesi $\boldsymbol{d}$ fikrasında, bilgi edinme hakkı kanununun uygulamasında gerekli olan özen ve hassasiyetin gösterilmesine yer verilmiştir.

Bu itibarla; "Dilekçe Hakkının Kullanılmasına Dair Kanun" ile "Bilgi Edinme Hakkı Kanunu" hükümlerinin gereklerinin genelgede ayrıntılı olarak ifade edilmesi, ilgili kanunların pratik hayatta uygulama sonuçlarını artırıp kurum ve kuruluşları, vatandaşa karşı daha sorumlu davranmaya yöneltmiştir.

\section{6/3 Sayılı Başbakanlık İletişim Merkezi (BIMER) - Doğrudan Başbakanlık Konulu Genelge}

20 Ocak 2006 tarihli ve 26055 sayılı Resmi Gazetede "Başbakanlık İletişim Merkezi (BİMER) Doğrudan Başbakanlık” konulu Başbakanlık Genelgesi yayımlanmıştır. Bilgi edinme hakkının bir türevi olarak, Başbakanlık, ilgili tüm kamu kurum ve kuruluşları üzerinden doğrudan kendisine müracaat edebilme yolunu vatandaşlara açmıştır. Bu genelge, vatandaşların BİMER'e yapacakları başvuruların tüm yurt çapında kabulünü ve izlenebilmesini (ayrıca, Demirci 2015), kurumlar arasında yönlendirilmesini ve vatandaşa geri dönülmesini sağlayan bir düzenleme hayata geçirilmiştir.

Genelgenin gerekçeleri arasında, literatürde öne çıkan 'yönetişim' ve 'yönetime katılma' kavramları/değerleri bulunmaktadır. Söz konusu genelge, yönetimde bir yöntem olduğu kadar birer (kamu) değerini de ifade eden bu kavramlar üzerinden, vatandaşların idareye ilişkin şikâyet, talep, görüş ve önerilerini kolayca iletebilmelerini, demokrasinin gerekliliği ve idarenin başarısı olarak değerlendirmektedir. Genelge ile BİMER, vatandaşlardan idareye ulaşacak şikâyet, talep, görüş, öneri ve memnuniyetlerin derhal işleme alınıp değerlendirilmesi, ilgili kuruma intikal ettirilmesi, sonuçlandırılmasının takibi bağlamında oldukça önemli bir uygulamadır. Herhangi bir müracaatın ilgilisine süratle cevap verilmesi kavramsal anlamda önemli olup, kamu kurum ve kuruluşlarının geleneksel halkla ilişkiler kavramında ciddi bir dönüşümü içeren yeni bazı düzenlemelerin yapılmasını da gerektirmiştir. 
Genelgeye göre, sistemin kuruluş ve işleyişi ile ilgili olarak 1. maddede, halkla ilişkiler büroları ve personelinin görevlendirilmesine değinilmiştir. 2. maddede, 150 numaralı kısa telefon hattı tahsisine gönderme yapılmakta; ayrıca, web üzerinden ilgili ara yüz programı kullanılarak sisteme nasıl giriş yapılacağı açıklanmaktadır. Üçüncü maddede, ilgili tüm birimlerce gerekli alt yapı sisteminin kurulması gereğine vurgu yapılmaktadır. 4. maddede, 4982 ve 3071 sayılı kanunlar ile insan hakları ihlallerine ilişkin müracaatların da BİMER üzerinden yapılabileceğine değinilmiştir. 5. Maddede, yapılacak müracaatların tek bir hat üzerinden yapılması ve müracaat sürecinin hem merkezileşmesi hem de basitleştirilmesi vurgulanmıştır. 6. maddede ise BİMER fiziki alt yapısının hazır olması gereken nihai tarih belirtilmiştir.

\section{Kamuda İnovasyon ve BIMER Uygulaması}

$\mathrm{Bu}$ kısımda, çalışmanın saç ayaklarından birini oluşturan inovasyon kavramına ve BİMER uygulamasının idarede nasıl bir inovasyonu sağlayabileceğine ilişkin seçilmiş bazı örnekler üzerinden bir çerçeve çizilecektir. Bu çerçevede, BİMER’e ulaşan girdiler, ilgili kamu kurumuna yönlendirilmesinin dışında, eğer kamu politikası geliştirmede kullanılabilecek birer içsel girdi olarak görülebilirse, idarenin zaman içerisinde, vatandaştan gelen şikâyetleri ciddi oranda azaltabilecek, gelen öneri ve memnuniyetleri gittikçe artırabilecek inovatif bir yapıya sahip olabilme potansiyeli öne çıkarılacaktır. Bu kısımda, önce inovasyon kavramı, kamuda inovasyon ve BİMER uygulaması kısaca anlatılacaktır.

Kavramın Latince "yenilenmek” demek olan köküne (innovare) gönderme yapan Arpacı, (2011), kavram ile kastedilenin salt iyi bir fikir veya ürün/hizmet geliştirmeden çok daha ötesi olduğunu tespit etmektedir. Dolayısıyla, örgütlerde inovasyon kavramının dönemsel değil, sürekli iyileşmeyi içerisinde barındırdığı görüşüne katkı vermektedir. Bu bağlamda değerlendirilirse, inovasyon kavramı, değişen oran ve ölçülerde özel, sivil veya kamu örgütlerinin hepsinde söz konusu olabilen bir süreçtir ${ }^{20}$. Ekonomik İşbirliği ve Kalkınma Örgütü (OECD), özellikle kamu örgütlerinde inovasyon olgusunu oldukça önemsemektedir (Arpac1, 2011; OECD 2009; OECD 2011).

"Örgütlerde niteliksel değişimler meydana getirebilecek etkiye sahip yöntem ve süreçler bütünü olarak inovasyon" kurumlarda teknolojik, sosyal ve örgütsel olmak üzere üç şekilde görülmektedir (Şengül, 2015, s. 142). İnovasyon, özellikle, teknolojik yeni bir ürün veya yöntem şeklinde, eskiye oranlı daha yüksek performanslı ürünün geliştirilmesi bağlamında söz konusudur (Şengül, 2015). Şengül'e göre (2015), Türkiye'de kamu sektöründe inovasyon çalışmaları hız kazanarak,

20 Aslında, inovasyon ve rekabet baskısı ilişkisi dikkate alınsa, inovasyonun daha çok özel sektör firmaları bağlamında söz konusu olan bir süreç olduğu dikkati çekmektedir. Yalnız, son dönemler itibariyle de, rekabet unsurunun yok denecek kadar az olduğu düşünülen kamu sektöründe de, inovasyona dönük baskılar söz konusudur. Rekabet olmasa da, başta maliyetlerin azaltılması, daha iyi kamu hizmeti sunulması, vatandaşın azalan/yok olan güveninin tekrar tesis edilmesi ve BİTlerin gelişmesi vd. unsurlar bağlamında, kamu sektörü de inovatif süreçlerle tanışmak, kamuda inovasyonu geliştirmek durumundadır (Borins, 2002). 
2006 yılından itibaren "Bilgi Toplumu Stratejisi ve Eylem Planı” çerçevesinde, özellikle, e-devlet alanında birçok proje çerçevesinde, kamuda inovasyon kavramı giderek daha gözle görülür bir nitelik kazanmıştır. Bu bağlamda, Şengül (2015) OECD üye ülkelerin katkılarıyla yürütülen "Kamuda İnovasyon Projesi” kapsamında pilot sürümü yayınlanan platformda kamu sektöründe öne çıkarılan 102 adet inovatif örnek arasında, Türkiye’den e-Devlet Kapısı, BİMER, UYAP olmak üzere 3 adet inovatif örnek yer aldığını öne çıkarmaktadır.

BİTlerin, diğer unsurların yanında, kamuda inovasyon sürecinde son derece önemli bir işlevselliği bulunmaktadır. Bu konuya ilişkin olarak, başta internet olmak üzere diğer BİTlerin kamu sektöründe, devlet-vatandaş ilişkisini daha önce örneği görülmemiş bir düzeyde dönüştürdüğü gözlenmektedir. Ayrıca, özellikle internetin kamuda inovasyon ve yeniliklerin hayata geçirilmesi bağlamında sunduğu olanaklar gözle görülür niteliktedir (Contini \& Lanzara, 2009). Özellikle vatandaşın kamu hizmetleri bağlamında karşılaştıkları olumlu - olumsuz yönleri idareye "veri” veya "girdi” olarak sağlayabilmesi sonucunda, idarenin salt bu müracaatı çözümlemekle kalmayıp, sonuçta "kamu yönetiminin iş görme biçimini” veya "kamu hizmetlerinin örgütlenme ve sunulma biçimini” değiştirebilmesi, kamuda inovasyon açısından yaşamsal bir destek sağlayabilir. Çünkü Misuraca ve Viscusi (2015) kamunun son dönem itibariyle karşılaştıkları sorunları çözmeye ilişkin bir sürü yeni yatırım yapmasına karşın, yeni yol ve yöntem geliştirmede ciddi bir sıkıntı yaşadığını belirtmektedir. Yaşanan bu zorluğun, teknik sorunlardan ziyade, kamu hizmeti üreten kamu kurumlarının örgütlenme biçimleriyle ilgili olduğu saptaması yapılmaktadır (Misuraca \& Viscusi 2015).

Bu bağlamda değerlendirilirse, BİMER uygulaması, özünde vatandaşın, Başbakan'a ${ }^{21}$ ulaşarak, karşılaştı̆̆ı bir sorunu, sıkıntıyı, uygulamayı seçilmiş en üst siyasal kimlik olarak Başbakanın manevi şahsında idarenin işlevsel olan en üst makamına iletmesi amacı taşımaktadır. Salt böyle bir amaç bile oldukça değerlidir. Bunun yanında, BİMER uygulamasının, idare-vatandaş arasında güven sağlama potansiyeli bağlamında da önemsenmelidir. Güven tesisi için, vatandaşların BİMER bağlamında yönetime katılmaları da sistem içerisinde kurgulanabilmelidir. Vatandaşların öneri veya şikâyetlerini BİMER marifetiyle dile getirmeleri, bireylerin yönetime katılmaları ve yönetişimin gerçekleşmesi bakımından önemlidir (Demirci, 2015).

21 Dönemin Başbakanı Sayın Erdoğan, vatandaşın bizatihi kendisine ulaştı̆̆ı hissinin verilmesine oldukça özen göstermiştir. Bu hissin verilebilmesi, hem vatandaş hem de idare nezdinde önemlidir. Şimdi vatandaş tarafından doğrudan seçilmiş en üst siyasal kimlik olan "Cumhurbaşkanı” sıfatını taşıyan Sayın Erdoğan’n, benzer bir uygulamayı (halk arasında CİMER olarak bilinen bir uygulamayı), Cumhurbaşkanlığı makamında gerçekleştirmek istemesi söz konusudur (T.C. Cumhurbaşkanlığı, t.y.). Elbette bu uygulamanın, Sayın Erdoğan’ın bizatihi şahsıyla ilişkili olmasının yanında, artık idari şemamızda yer alan en üst seçilmiş makamın Cumhurbaşkanlığı olmasının etkisi de vardır. Elbette, Cumhurbaşkanlığı’nın idari şemamızdaki işlevselliği, an itibariyle eskisi gibi olsa da (siyaseten sorumluluğu olmayan, temsil makamında doğrudan halk tarafından seçilmiş bir Cumhurbaşkanı), anayasa değişikliği çerçevesinde T.B.M.M Genel Kurul'unda görüşülen ve ilk tur oylamaları tamamlanan Cumhurbaşkanlığı (başkanlık) sisteminin hayat bulması öngörülmektedir. Söz konusu anayasa değişikliğinde, sisteme yönelik getirilmesi planlanan başka değişikliklerin yanında, idari şemamızda Başbakanlığın kaldırılması; yerine Cumhurbaşkanlığı’nın gelmesi tasarlanmıştır. Bu özellikle, söz konusu CİMER uygulamasının işlevselliği bağlamında yaşamsaldır. Aksi halde, şahsa veya duruma bağlı bir işlevsellik söz konusu olabilecek; ayrıca, bu işlevselliğin kurumsallaşamaması oldukça önemli bir eksiklik olarak kalacaktır. 
Devlet ile vatandaşları arasındaki etkileşimin düzenlenmesinde, diğer unsurların yanında, toplumsal yapıda öne çıkan özelliklerin bilinmesi de katkı sağlayacaktır. Bu noktada, vatandaşın idareden ne gibi beklentileri olduğunun yanında, söz konusu beklentileri hangi sıklıkla ve hangi yöntemler kullanarak dile getirdiği önemlidir. Diğer taraftan, idarenin örgütsel olarak, bunu karşılayabilme yeteneğinin yanında, örgütlenme biçimi de öne çıkmaktadır (Kazancı, 2013). $\mathrm{Bu}$ nedenle, kamu yönetiminde halkla ilişkiler sürecinin değişen paradigmalarla yeniden kurgulanabilmesi (vatandaşın "diğerleri” değil, sürecin bir paydaşı veya tarafı olması ${ }^{22}$ ), vatandaşın devlete duyduğu güvenin artmasında ve demokratikleşme sürecinin sağlıklı gelişmesinde önemlidir. Bu çerçevede, bilgi edinmenin bireyler için bir hak olarak kabul edilmesi; aynı zamanda, bilgi ve belge sağlamanın ise kamu kurumları açısından bir yükümlülük olması (İbiş \& Akdağ, 2015) süreç için önemli aşamalardır. BİMER gibi uygulamalar idareye önemli sorumluluklar yüklemektedir. Bu sorumluluğun başarıla gerçekleştirilebilmesi için tek elden ve tek merkezden koordineli bir biçimde, müracaatların ilgili kuruma intikali, tüm sürecin takibi, müracaatçıların bilgilendirilmesi, gecikme olması durumunda ilgili kurumun uyarılması, denetlenebilmesi ve istatistiksel raporlamanın yapılması önemlidir (Sayan, 2014; Bozkurt, 2010).

\section{BIMER'in Kamuda İnovasyon Sürecine Katkı Verebilmesi}

Vatandaş tarafindan önemli bir başvuru merkezi olarak görülen BİMER’e yapılan başvuru sayısı ve BİMER'de gerçekleştirilen işlem sayıları Tablo 1'de görüldüğü gibi, her geçen yıl artan bir seyir izlemektedir.

Tablo I: BIMER Müracaat ve İşlem Sayıları

\begin{tabular}{|c|c|c|}
\hline \multicolumn{2}{|c|}{ Yıllara Göre BİMER'e Gelen Başvuru Sayıları } & Yillara Göre BİMER'de Gerçekleştirilen İंşem Sayıları \\
\hline Yıllar & Başvuru Sayısı & İşlem Sayıs \\
\hline 2006 & 129.297 & 172.470 \\
\hline 2007 & 137.716 & 208.899 \\
\hline 2008 & 217.859 & 343.627 \\
\hline 2009 & 384.852 & 583.697 \\
\hline 2010 & 649.115 & 926.955 \\
\hline 2011 & 822.287 & 1.415 .336 \\
\hline 2012 & 866.885 & 1.743 .293 \\
\hline 2013 & 1.168 .853 & 2.592 .057 \\
\hline 2014 & 1.124 .005 & 2.766 .360 \\
\hline 2015 & 1.267 .665 & 3.859 .240 \\
\hline
\end{tabular}

Kaynak: http://www.bimer.gov.tr/Forms/pgReports.aspx

22 Şu nokta oldukça önemlidir: İdare tek başına, gelişen olanak ve kendi örgütsel kabiliyeti çerçevesinde kamu değeri de üretebilir, inovatif yöntemler de geliştirebilir, fakat başta bireyler olmak üzere, başkalarından yardım alması veya onlarla işbirliğine gitmesi, tek başına üreteceği her şeyden daha fazla olacaktır (Millard, 2013). 
Başvuru ve işlem sayılarındaki artan oranlı yükseliş, devlet - vatandaş etkileşiminin değişim yapısına ilişkin eğilim hakkında da fikir vermektedir. Bilginin devlet ve vatandaş arasında artan oranlı paylaşımı, karşılıklı iki yönlü bir güven ortamının oluşumuna yardımcı olmaktadır (Bulduklu \& Türkmenoğlu, 2015). Elbette BİMER özelinde veya bilgi edinme hakkı genelinde, giderek artan oranlı bir bilgi edinme talebi olumlu olarak algılanabilir. Aynı zamanda, artan oranlı talep, muhatap bulma, sorunlarını iletme, çözüm bulma gibi konularda olumsuz bir durum olarak da algılanabilir. Özellikle inovasyon bağlamında değerlendirilirse, bu durumun önce artan oranlı ama zaman içerisinde azalan oranlı olması gerekirdi. Yani, idare, kendisine gelen müracaatları, salt bir bilgi edinme müracaatı olarak görmeyip, aynı zamanda birçok vatandaşın muhtemel benzer sorunları yaşaması bağlamında değerlendirmelidir. Elbette her müracaatın içeriği genellenebilir olmayabilir. Ama toplumun bir kesimine, zümresine veya belli bir guruba yönelik genellenebilir müracaatların kamu kurumlarının yapılanmasında yenilik veya kamu hizmetlerinin görülmesinde bir yenilik sağlayabilecek boyutuyla da değerlendirebilir. Böyle bir durumun BİMER'e intikali ile hem durumun ilgili idareye intikali sağlanabilir, hem de bu durumu idarenin tamamına yayılabilir. O zaman başta benzer müracaatlar olmak üzere, idareye başvuruların zaten azalması gerekirdi. Bu noktada bir uygulama örneği olarak T.C. Salihli Belediyesi 1.2.2016 tarihli, 2016/29 sayılı meclis toplantı kararından bir kesit verilecektir.

İlgili belediye meclis kararında, BİMER'e giden bir müracaata gönderme yapılmakta, söz konusu vatandaşın esnafın yaya kaldırımını işgal etmesi kaynaklı bir şikâyeti paylaşılmaktadır (T.C. Salihli Belediyesi, t.y.). Bu durumun ilçe belediyesinin üç adet caddesinde de söz konusu olduğuna dikkat çekilmektedir. Belediye başkanı da konuşmasında konu ile ilgi olarak BİMER'de şikâyetlerin bulunduğunu, bu aşamaya gelmeden bir an evvel komisyon ve encümen kararları ile gereğinin yapılmasına değinmiştir. Bir bütün olarak bakıldığında, belirtilen soruna çözüm ciddiyetinin oluşmasında, vatandaşın BİMER'e şikâyet ve çözüm bulunması için başvurması önemlidir. Belediye açısından sorunun hızlı ve etkin çözümü yoluna gidilerek, belediye ve vatandaşlar arasında bir güven ortamı oluşturulmaya çalışıldığı görülmektedir. Bu güven ortamı, sorunların üst merciye müracaat gerekmeden ilgili sorunun belediyeye intikali ile çözülebilmesinin gösterilmesi açısından çok önemlidir. BİMER açısından ise, bu müracaatın örnek bir şikâyet olması bağlamında, böyle bir durumun tüm il, ilçe ve belde belediyelerinde yaşanabileceği öngörülebilmelidir. Bundan hareketle, BİMER başbakanlık adına ilgili tüm yerel yönetimlere böyle bir sorunun varlığından bahisle - kamu yararı gerekçesiyle - konu ile ilgili düzenlemelerin yapılmasını talep edebilir ${ }^{23}$.

Böylece, benzer başka sorunların BİMER’e gelmesinin önü alınacağı gibi, daha sorunlar ortaya çıkmadan çözülmesi sağlanabilir ${ }^{24}$. Her şeyden önemlisi, BİMER yardımıyla, müracaatçının

23 Başbakanlığın, yerel yönetimler üzerinde hukuken böyle bir yetkisi yoktur. İdari vesayet, yerel yönetimlerin eylem ve işlemlerinin hukuksal uygunluğunu denetleme kabiliyeti vermektedir. Bu noktada BİMER, kamu yararı gerekçesiyle böyle bir düzenlemenin yapılmasını tavsiye edebilir, yapılmasında ısrar edebilir. Bunun yanında, vesayet yetkisinin hiyerarşik yetki olmaması gerekçesiyle, BİMER çerçevesinde Başbakanlığın yerel yönetimler üzerinde böyle bir yetki sağlama sürecinin başlatılması dahi kanaatimizce bir inovasyon örneğidir.

24 Benzer kaldırım işgali sorunları ve olayların BİMER’e intikali için bkz. http://www.kayseriolay.com/develi-de-esnaflararasinda-kaldirim-davasi-h12014.htm ve http://www.aydindenge.com.tr/guncel/19/04/2013/esnaf-belediyeyi-belediyebimeri-dinlemiyor. 
kendisini dinleyecek, bilecek ve cevap verecek bir mercinin varlığını hissetmesi, müracaatı olumsuz sonuçlansa bile, son derece önemlidir. Çünkü sahipsizlik duygusu, idare-vatandaş arasındaki güven olgusuna ciddi zarar verir. Sahiplik duygusu birey açısından psikolojik, toplum açısından ise sosyolojik bir fayda temin etmektedir (ayrıca, Ağır \& Turhan, 2014). Diğer yandan yurttaşlar ile devlet arasında geleneksel ilişkideki orantısız gücün varlığı ve bunun kullanılma potansiyeli, idareden "korkmaya" sebep olmaktadır ${ }^{25}$. Bu noktada, BİMER'in aracısız bir biçimde, vatandaşların devlet ile olan ilişkilerinde ve onun karşısındaki konumunu güçlendirmesinde katkı sağlaması olanaklıdır.

Son dönem devletin ve milletin bekasına ilişkin ihbar etme teşviki de dikkate alınırsa, genel olarak bilgi edinme süreci, özel olarak da BİMER süreci, "ihbar etmeyi” idare tarafından teşvik edilen ve vatandaşlar tarafından da tercih edilen yaygın bir uygulama haline getirmiştir. Bu nedenle her iki taraf için son derece hassas olunması gereken bir süreç oluşmuştur. İhbarcıların, sorunları idareye haber verme, bildirme uygulamaları intikam niyeti taşıyabilir ve her zaman gerçeği yansıtmayabilir. Diğer yandan bu süreçte ihbarcıların korunmadığı ve korunmayacağı endişesi, kimlik bilgilerinin açıklanmak istenmemesine yol açmaktadır. Örneğin, BİMER sistemine, Eylül 2011 - Temmuz 2015 tarihleri arasında gerçekleştirilen toplam 203.912 (adet) başvuru içerisinde, 110.835 (adet) başvuru, kimlik bilgileri gizli tutulmak (\% 54) suretiyle yapılmıştır (Candan \& Kaya, 2015). Buradan hareketle, her süreçte olduğu gibi, bilgi edinme ve BİMER süreçlerinde de idarenin dikkat etmesi, art niyetli kullanıcıların varlığını tespit ederek, sürecin bu amaçla tekraren kullanımının önüne geçmesi, ayrıca, başka bireylerin de söz konusu süreçleri art niyetli kullanımlarının önlenmesi yaşamsaldır.

\section{Sonuç}

Şurası açıktır ki, günümüzde bireyler giderek karmaşıklaşan bir toplumsal yapı içerisinde yaşamaktadır. Söz konusu karmaşıklık, salt bireysel veya toplumsal yaşamlarda değil, aynı zamanda karşılaşılan sorunlar bakımından da geçerlidir. Bu çerçeveden değerlendirilirse, yönetimlerin birey ve gruplarla olan etkileşimini, bilişim ve iletişim kanalları ile desteklemek durumundadır. Söz konusu, iletişim ve bilişim kanallarının, içinde bulunulan değişimler ve dönüşümler paralelinde güncellenmesi, yönetimlere salt vatandaşları ile kaliteli bir etkileşim sağlamakla kalmayacak, aynı zamanda, ortaya çıkması olası birçok soruna proaktif bir biçimde çözüm üretmesini de sağlayacaktır.

Halkla ilişkiler anlayışı, geleneksel olarak, idarenin kendisini vatandaşlarından ayrı tutması bağlamında şekillenmiş olup, vatandaşların idareyi dışsal bir unsur olarak uzaktan denetlemesi bağlamında kurgulanmıştır. Hâlbuki söz konusu halkla ilişkiler anlayışı, etrafta gerçekleşen değişimi algılama ve ona yön verip yöneltmede idareye yol gösterici olabilse, idare vatandaşların başvuruları sayesinde oldukça fazla girdi alabilir. Bu girdi idarenin sürekli iyileştirilmesi

25 Yozgat-Yerköy'de belediyeyi BİMER’e şikayet eden bir vatandaşa dönük belediyenin eylem ve işlemleri aktarılmaktadır.Bkz. http://www.haber3.com/belediyeyi-bimere-sikayet-etti-tandirligindan-oldu-1626914h.htm. 
amacıyla kullanılabilir. Bu noktadan hareketle, idarenin topluma olan katkısı, diğer yandan vatandaşın idareye olan katkısı, karşılıklı olması ve vatandaşın artık bir paydaş olarak görülebilmesi çerçevesinde, halkla ilişkiler sürecinin başarılı dönüşümünün bir göstergesi olarak değerlendirilebilir.

Vatandaşa hizmet etmenin varlık sebebi olduğu kamu kurumlarında, bu kurumlar vatandaşların istek, şikâyet, beklenti ve memnuniyetleri sürekli ölçebilmelidir. Daha önce ifade edildiği gibi idarenin kamu hizmeti ve kamu yararı üretmesi, vatandaşın dâhil olmadığı bir süreç çerçevesinde de olanaklıdır. Bu şimdiye kadar, çoğunlukla da böyle olmuştur. Bununla birlikte, idarenin vatandaştan veri alarak bu süreci çok daha iyileştirmesi olanaklıdır. Dolayısıyla bu çalışma, idarenin gelişen teknolojiler paralelinde ortaya çıkan olanakları olumlu biçimde kullanması bağlamında, sürekli iyileşme olarak da tarif edebileceğimiz inovasyonun gerçekleşebileceği ön kabulü üzerinden ilerlemektedir. Başta bilgi edinme hakkı olmak üzere, BİMER uygulaması, idarenin vatandaşlarından - karşılıklılık esası temel alınarak - son derece önemli girdi ve veri alabilmesinin önünü açmaktadır.

Sonuç olarak, BİMER'in yayınlanan verileri incelendiğinde vatandaşların giderek artan bir oranda bu sistemi kullandığı görülmektedir. Sebebi her ne olursa olsun, giderek artan bir kullanım ile oldukça değerli veriler ve girdiler elde edilebilir. Bu çerçevede idare vatandaşları ile olan etkileşiminde geleneksel olarak geliştirdiği reaktif tavır yerine, proaktif bir tavır geliştirebilir. 


\section{Kaynakça}

Ağır, O., \& Turhan, A. (2014). Demokratik Toplumda Bilginin Önemi ve Bilgi Edinme Hakkı Kanunu. İnönü Üniversitesi Hukuk Fakültesi Dergisi, 5(2), 283-312.

Akkaya Kia, R. (2013). Devlet Sırrı, Kimin Sırrı?. Marmara Üniversitesi Hukuk Fakültesi Hukuk Araştırmaları Dergisi (MÜHF-HAD) Armağan Özel Sayısı, 19(2), 749-755.

Akyıldız, F., \& Demir, F. (2011). Beşinci Yılında Bilgi Edinme Hakkı: Uşak İli Örneği. Celal Bayar Üniversitesi Sosyal Bilimler Dergisi, 9(2), 588-612.

Akyürek, R., \& Solmaz, B. (2003). "Evaluation of "Public Relation" Descriptions According to the

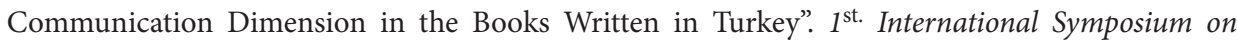
Communication in the Millennium: A Dialogue between Turkish and American Scholars Vol. 1 içinde (pp. 387-402), 19-21 February, U.S.A.

Aras, Z., \& Altınok, E.B. (2009). Türkiye'de Bilgi Edinme Hakkı ve Uygulama Sorunları, Ankara Barosu Dergisi, 67(1), 107-112.

Arpacı, İ. (2011). Kamu kurumlarında teknolojik inovasyon ve inovasyon politikası. ODTÜ Gelişme Dergisi, 38(2),111-123.

Asna, A. (2012). Kuramda ve Uygulamada Halkla İlişkiler, İstanbul: Pozitif Yayınları.

Aydın, M. (2004). 1982 Anayasası’nda Türkiye Büyük Millet Meclisi’ne Bireysel Başvuru Hakkı ve Uygulaması. Gazi Üniversitesi Hukuk Fakültesi Dergisi, 8(1-2), 293-328.

Başok, N., \& Coşkun, G. (2012). Teoriden Pratiğe Halkla İlişkiler Projeleri: Ödüllü Örnek Uygulamalar, Ankara: Nobel Yayınevi.

Borins, S. (2002). Leadership and innovation in the public sector. Leadership \& Organization Development Journal, 23(8), 467 - 476.

Bozkurt, A. (2010). BİM’leri tanıyoruz - Başbakanlık BİB. Bilişim (Aylık Bilişim Kültürü Dergisi - Türkiye Bilişim Derneği),125,108-115.

Bulduklu, Y., \& Türkmenoğlu, A. T. (2015). Bilgi Toplumunda Kamu Kurumlarının Bilgi Edinme Birimleri ve Halkla İlişkiler. Hacettepe Üniversitesi Türkiyat Araştırmaları Dergisi, 22, 47-64.

Candan, H., \& Kaya, T. P. (2015). İhbarcılık (Whistleblowing) ve Algılanan Örgütsel Destek Arasındaki İlişkinin İncelenmesine Yönelik Bir Kamu Kurumunda Araştırma. Kahramanmaraş Sütçü İmam Üniversitesi İktisadi ve İdari Bilimler Fakültesi Dergisi, 5(2), 305-330.

Contini, F., \& Lanzara, G. F. (2009). "Introduction". In ICT and Innovation in the Public Sector: European Studies in the Making of E-Government. Francesco Contini and Giovan Francesco Lanzara (eds.), Palgrave Macmillan, UK.

Çevikbaş, R. (2006). Yönetimde Etik ve Yozlaşma. Atatürk Üniversitesi İktisadi ve İdari Bilimler Dergisi, 20(1), 265-289.

Çımat, A. (1997). Türkiye’de Gizliliğin Yasal Temelleri ve Açılık. Vergi Raporu, 30, 19-26.

Demirci, K. (2015).Türkiye’de Yurttaş- Devlet İletişimi Açısından E-Devlet Uygulamaları: BİMER Örnek Olayı. Akdeniz İletişim (Akdeniz Üniversitesi İletişsim Fakültesi Dergisi), 23, 98-114.

Demirkol, S. (2012). Kamu Denetçisi (Ombudsman) Kurumunun Etkinliğinin Sağlanması ve Yargıyla İlişkisi Hakkında Kıyaslamalı Bir Çalışma Taslağı. İdare Hukuku ve İlimleri Dergisi, 15(2), 45-72.

Efe, H., \& Demirci, M. (2013). Ombudsmanlık Kavramı ve Türkiyede Kamu Denetçiliği Kurumundan Beklentiler. Sayıştay Dergisi, 90, 49-72.

Eken, M. (1994). Kamu Yönetiminde Gizlilik Geleneği ve Açıklık İhtiyacı. Amme İdaresi Dergisi, 27(2), 2554. 
Fendoğlu, H. T. (2013). Kamu Denetçiliği (Ombudsmanlı) ve Anayasa Mahkemesine Bireysel Başvuru Hakkı. Ankara Barosu Dergisi, 2013/4, 21-49.

Güran, S. (1982). Yönetimde Açıllık. İdare Hukuku ve İlimleri Dergisi, 3(1-3), 101-112.

Hatipoğlu, C. (2014). Vergisel Uyuşmazlıklar Bakımından Kamu Denetçiliği Kurumuna Başvuru Koşulları. Marmara Üniversitesi Hukuk Fakültesi Hukuk Araştırmaları Dergisi, 20(2), 309-330.

Harlow, R. F. (1975). Management, public relations, and the social sciences. Public Relations Review, 1(1), 5-13.

Harlow, R. F. (1976).Building a Public Relations Definition. Public Relations Review, 2(4), 34-42.

Harlow, R. F. (1977). Public relations definitions through the years. Public Relations Review, 3(1), 49-63.

Harlow, R. (1980). A timeline of public relations development. Public Relations Review, 6(3), 3-13.

Hasdemir, T. A. (2014). Türkiye’de Kamusal İletişim ve Bilgi Edinme: 10 Yılın Ardından Panoramik Bir İnceleme. Amme İdaresi Dergisi, 47(3), 111-144.

http://www.aydindenge.com.tr/guncel/19/04/2013/esnaf-belediyeyi-belediye-bimeri-dinlemiyor.

http://www.haber3.com/belediyeyi-bimere-sikayet-etti-tandirligindan-oldu-1626914h.htm.

http://www.hurriyet.com.tr/bimere-sikayet-dagin-altinda-hazine-var-40128272).

http://www.kayseriolay.com/develi-de-esnaflar-arasinda-kaldirim-davasi-h12014.htm.

İbiş, H., \& Akdağ, M. (2015). Bilgi Edinme Kanunu’ndan Yararlanma Sıklı̆̆ı: Erciyes Üniversitesi Örneği (2011-2014). Erciyes Üniversitesi Sosyal Bilimler Enstitüsü Dergisi, 38, 157-174.

İnaç, H., \& Ünal, F. (2007). Türkiye’de Kamu Yönetiminin Denetlenmesinde Yönetimde Açıklığın Önemi ve Uygulanma Düzeyi. Dumlupınar Üniversitesi SBE Dergisi, 18, 41-62.

Kazanc1, M. (2013). Kamuda ve Özel Kuruluşlarda Halkla İlişsiler. Ankara: Turhan Kitabevi Yayınları.

Kırışık, F. (2013). İdare ile Bireyler Arasındaki İlişkilerde Güç Dengesizliğinin Giderilmesinde Etkili Bir Yöntem: İdari Usul. Dumlupınar Üniversitesi Sosyal Bilimler Dergisi, 37, 245-252.

Küçük, A. (2011). Bilgi Edinme Hakkının Sınırları ve Bu Hakkın İhlalinde İdare ve Kamu Görevlilerinin Sorumluluğu. Sayıştay Dergisi, 81,111-139.

Külcü, Ö., \& Turan, M. (2013). Kamu Hukukunda Geleneksel ve Elektronik İletişim, Bilgi ve Belge Yönetimi Uygulamaları. Türk Kütüphaneciliği Dergisi, 27(2), 266-300.

Millard, J. (2013). "ICT-enabled public sector innovation: trends and prospects". In Proceedings of the $7^{\text {th. }}$ International Conference on Theory and Practice of Electronic Governance (ICEGOV '13), Tomasz Janowski, Jeanne Holm, \& Elsa Estevez (Eds.) ACM, New York, NY, USA, 77-86. DOI=http://dx.doi. org/10.1145/2591888.2591901.

Misuraca, G. \& Viscusi, G. (2015). Shaping public sector innovation theory: an interpretative framework for ICT-enabled governance innovation. Electronic Commerce Research,15(3), 303-322.

OECD. (2011). Together for Better Public Services: Partnering with Citizens and Civil Society, OECD Public Governance Reviews, OECD Publishing, Paris, DOI: http://dx.doi.org/10.1787/9789264118843-en.

OECD. (2009), Focus on Citizens: Public Engagement for Better Policy and Services, OECD Studies on Public Engagement, OECD Publishing, Paris, DOI: http://dx.doi.org/10.1787/9789264048874-en.

Polater, Y. Z. (2016). Bilgi Edinme Hakkının Sınırları ve Devlet Sırrı. Türkiye Barolar Birliği Dergisi, 122, 99-140.

Sayan, İ. Ö. (2014). Türkiye'de Ombudsmanllk Kurumunun Uygulanabilirliği ve Alternatif Denetim Yöntemleri. Ankara Üniversitesi Siyasal Bilgiler Fakültesi Dergisi, 69(2), 333-349.

Şaylan, G. (2000). Kamu Yönetimi Disiplininde Bunalım ve Yeni Açllımlar Üzerine Düşünceler. Amme İdaresi Dergisi, 33(2), 1-22. 
Şengül, R. (2005). Bilgi Edinme Hakkı Kanunu Türk Kamu Yönetimini “Camdan Eve” Dönüştürür mü?, Ankara Üniversitesi Siyasal Bilgiler Fakültesi Dergisi, 60(3), 215-234.

Şengül, R. (2008). Bilişim Çağında Şeffaf Yönetim. Ankara: Nobel Yayın Dağıtım.

Şengül, R. (2015). Örgütsel Değişim Faktörü Olarak İnovasyon ve Kamu Yönetimi. Eskişehir Osmangazi Üniversitesi İktisadi ve İdari Bilimler Fakültesi Dergisi, 10(2), 141- 151.

T.B.M.M. (t.y. a). Bilgi Edinme Hakk 12 Eylül 2010 Tarihli Anayasa Değişikliği ile Anayasaya Girdi. https:// www.tbmm.gov.tr/bilgiedinme/2010_raporu_baskanlik_aciklamasi.pdf (Erişim Tarihi: 13.01.2017).

T.B.M.M. (t.y. b). Dilekçe. https://www.tbmm.gov.tr/komisyon/dilekce/mevzuat.htm (Erişim Tarihi: 13.01.2017).

T.B.M.M. (t.y. c). Gül Hükümeti Programı. https://www.tbmm.gov.tr/hukumetler/HP58.htm (Erişim Tarihi: 13.0.2017).

T.B.M.M. (t.y. d). I. Erdoğan Hükümeti Programı. https://www.tbmm.gov.tr/hukumetler/HP59.htm (Erişim Tarihi: 13.01.2017).

T.B.M.M. (t.y. e). Bilgi Edinme Hakkı Kanununda Değişiklik Yapılmasına Dair Kanun Tasarısı. http://www2. tbmm.gov. tr/d22/1/1-0955.pdf (Erişim Tarihi: 13.01.2017).

T.C. Cumhurbaşkanlığı (t.y.). Cumhurbaşkanına Yazın. https://basvuru.tccb.gov.tr/Forms/pgDefault.aspx (Erişim Tarihi: 13.01.2017).

T.C. Başbakanlık. (t.y.). Başbakanlık İletişim Merkezi. http://www.bimer.gov.tr/Forms/pgMain.aspx (Erişim Tarihi: 13.01.2017).

T.C. Başbakanlık. (2003). Bilgi Edinme Hakkı Kanunu Tasarısı Genel Gerekçesi. http://www2.tbmm.gov.tr/ d22/1/1-0632.pdf (Erişim Tarihi: 13.09.2016).

T.C. Başbakanlık Bilgi Edinme Değerlendirme Kurulu (2014). Bilgi Edinme Hakkı Mevzuatı. Bilgi Edinme Değerlendirme Kurulu Yayınları 1, Ankara, http://www.bedk.gov.tr/Yayinlar/BEHMevzuati/BILGI_ EDINME_HAKKI_MEVZUATI_TR.html (Erişim Tarihi: 15.09.2016).

T.C. Başbakanlık BEDK (2015). BEDK Kararları Işı̆̆ında Açıklamalı Bilgi Edinme Hakkı Kanunu, BEDK Yayınları 4, Ankara, http://www.bedk.gov.tr/Yayinlar/AciklamaliBilgiEdinmeHakkiKanunu/index. html (Erişim Tarihi: 16.09.2016).

T.C. Salihli Belediyesi (t.y.). Salihli Belediyesi Meclis Kararı. http://www.salihli.bel.tr/external/ dokuman/2016_291455809257.pdf (Erişim Tarihi: 15.01.2017).

Türk Dil Kurumu. (t.y. a). Genel Türkçe Sözlük, http://tdk.gov.tr/index.php?option=com_ gts\&arama=gts\&guid=TDK.GTS.5878bb2e140669.85140865 (Erişim Tarihi: 13.01.2017).

Türk Dil Kurumu. (t.y. b). Genel Türkçe Sözlük, http://tdk.gov.tr/index.php?option=com_ gts\&arama=gts\&guid=TDK.GTS.5878bb325f4550.27263089 (Erişim Tarihi: 13.01.2017).

Yılmaz, H. (2015). Bilgi Edinme Hakkı Kanunu Kapsamında İtiraz Usulü. İnönü Üniversitesi Hukuk Fakültesi Dergisi Özel Sayı II, 965-986. 